P-ISSN: 2615-1723

E-ISSN: 2615-1766

April 2020
Jurnal Riset Pendidikan Dasar

03 (1), (2020) 41-50

Submitted: Januari, Accepted Februari, Published: April

\title{
IMPLEMENTASI MODEL PEMBELAJARAN EXAMPLE NON EXAMPLE UNTUK MENINGKATKAN HASIL BELAJAR TEMATIK
}

\author{
Tyaswati NA
}

\section{Sekolah Dasar Negeri Panjang 03, Semarang, Jawa Tengah, Indonesia}

Korespondensi. E-mail: tyasa3362@gmail.com

\begin{abstract}
Abstrak
Penelitian ini bertujuan untuk untuk meningkatkan hasil belajar dalam pembelajaran tema 1 Diriku pada siswa kelas 1A SD Negeri Panjang 03 Kabupaten Semarang menggunakan model pembelajaran Example Non Example. Jenis penelitian ini menggunakan penelitian tindakan kelas (PTK) yang terdiri dari dua siklus. Masing-masing siklus terdiri atas tahapan perencanaan tindakan, pelaksanaan tindakan, observasi, dan refleksi. Instrumen pengumpulan data menggunakan rubrik penilaian pelaksanaan aktivitas siswa, angket, dan lembar kerja siswa. Analisis data dilakukan menggunakan analisis komparatif yaitu membandingkan kondisi awal sebelum tindakan dengan hasil siklus I dan siklus II. Berdasarkan hasil pada pra siklus pada pembelajaran tema 1 Diriku dengan subtema 2 Tubuhku diperoleh data bahwa dari 24 siswa ada 13 siswa belum tuntas belajar (sesuai KKM yaitu $\geq 70$ ), sedangkan 11 siswa telah tuntas belajar. Persentase ketuntasan belajar siswa di kelas I A yaitu 46\% siswa tuntas dan 54\% siswa tidak tuntas. Tujuan penelitian ini adalah meningkatkan hasil belajar siswa melalui model pembelajaran Examples Non Examples siswa kelas I A. Subjek penelitian ini adalah siswa kelas I A SD Negeri Panjang 03 tahun pelajaran 2019/2020 yang berjumlah 24 siswa. Pengumpulan data diperoleh dari hasil tes dan observasi. Sedangkan analisis data meliputi data kualitatif dan data kuantitatif. Berdasarkan analisis data penelitian hasil tes formatif dari siklus 1 ke siklus 2 yaitu ada peningkatan hasil belajar siswa kelas IA melalui implementasi model pembelajaran Examples Non Examples. Hal ini dibuktikan dengan hasil belajar siswa yang mengalami peningkatan dari siklus 1 ke siklus 2. Pada siklus 1 ketuntasan klasikal sebesar $79 \%$ dan $100 \%$ pada siklus 2 .
\end{abstract}

Kata Kunci: Example Non Example, Hasil Belajar, Tematik-terpadu

\section{IMPLEMENTATION OF EXAMPLE NON EXAMPEL EXAMPLE LEARNING MODEL TO IMPROVE THEMATIC LEARNING OUTCOMES}

\begin{abstract}
This study aims to improve learning outcomes in learning theme 1 Myself in grade 1 A students of SD Negeri Panjang 03 Semarang Regency using the Examples Non Examples learning model. This type of research uses classroom action research (CAR) which consists of two cycles. Each cycle consists of stages of action planning, action implementation, observation, and reflection. The data collection instruments used the rubric of evaluating the implementation of student activities, questionnaires, and student worksheets. Data analysis was performed using comparative analysis which compares the initial conditions before the action with the results of cycle I and cycle II. Based on the results of
\end{abstract}

Copyright (C2020, JRPD, ISSN 2615 - 1723 (Print), ISSN 2615 - 1766 (Online) 
the pre-cycle learning theme 1 Myself with sub-theme 2 My body obtained data that from 24 students there were 13 students not yet finished learning (according to the KKM ie yaitu 70), while 11 students had finished learning. The percentage of students completeness learning in class IA is $46 \%$ students completed and $54 \%$ students not complete. The purpose of this study was to improve student learning outcomes through the learning model of Examples Non Examples of Class I students. The subjects of this study were Class I A students of SD Negeri Panjang 03 in the 2019/2020 academic year, totaling 24 students. Data collection was obtained from test and observation results. While data analysis includes qualitative data and quantitative data. Based on the analysis of research data formative test results from cycle 1 to cycle 2 namely there is an increase in the learning outcomes of IA class students through the implementation of the Non Examples Examples learning model. This is evidenced by student learning outcomes that have increased from cycle 1 to cycle 2. In cycle 1 classical completeness is $79 \%$ and $100 \%$ in cycle 2 .

Keywords: Example Non Example, Learning Outcomes, Thematic-integrated

\section{PENDAHULUAN}

Permendikbud nomor 24 tahun 2016 tentang kompetensi inti dan kompetensi dasar pelajaran pada kurikulum 2013 menyatakan bahwa pelaksanaan pembelajaran pada sekolah dasar dilakukan melalui pendekatan pembelajaran tematik-terpadu yang diterapkan di kelas dasar yaitu kelas I, II, dan III. Sedangkan Lisnani (2019: 77) berpendapat bahwa pembelajaran tematik-terpadu menekankan pada pendekatan saintifik (scientific approach) yaitu membangun pengetahuan menggunakan metode ilmiah yang berdasarkan langkah-langkah sains. Menurut Sundayana (2014: 30) penilaian pada penerapan kurikulum 2013 mencakup 3 ranah belajar yakni sikap dan perilaku, pengetahuan, serta keterampilan.

Berdasarkan pernyataan tersebut maka dapat disimpulkan bahwa kurikulum 2013 merupakan pembelajaran tematik-terpadu melalui pendekatan saintifik untuk mencapai hasil yang diharapkan pada penilaian sikap dan perilaku, pengetahuan, serta keterampilan.

Pada pembelajaran tematik-terpadu mengganti standar kompetensi (SK) dengan kompetensi dasar (KI) dan kompetensi dasar (KD). Hal ini diperoleh dari lampiran Permendikbud nomor 24 tahun 2016 tentang kompetensi inti dan kompetensi dasar pelajaran yang menyatakan bahwa kompetensi inti (KI) merupakan tingkat kemampuan siswa dalam mencapai standar kompetensi lulusan (SKL) pada setiap tingkat kelas. Sedangkan kompetensi dasar (KD) kurikulum 2013 berisi kemampuan dan materi pembelajaran pada masing-masing satuan pendidikan untuk suatu mata pelajaran yang mengacu pada kompetensi inti (KI).

Pembelajaran tematik-terpadu di SD Negeri Panjang 03 Ambarawa khususnya kelas 1 A telah mencoba menerapkan model pembelajaran yang menyenangkan untuk menumbuhkan minat belajar siswa sebagai upaya meningkatkan hasil belajar siswa. Namun, karena kurikulum 2013 merupakan hal baru bagi guru dan siswa maka hasil belajar yang diperoleh belum meningkat secara siqnifikan. Kurangnya pemahaman guru tentang penerapan pembelajaran tematikterpadu mengakibatkan kurangnya perhatian dan minat siswa pada proses pembelajaran. Hal ini terlihat dari hasil belajar siswa pada pembelajaran tema 1 Diriku dengan subtema 2 Tubuhku yang menunjukkan ada 13 siswa (54\%) masih di bawah KKM (70) pada kondisi awal (pra siklus). Sedangkan rata-rata hasil belajar kelas I SD Negeri Panjang 03 sebesar 69,7. Data tersebut menunjukkan rendahnya hasil belajar siswa pada tahun pelajaran 2019/2020 semester I.

Penyebab rendahnya hasil belajar siswa pada tema 1 Diriku dengan subtema 2 Tubuhku adalah kurang tepatnya penggunan model pembelajaran dengan materi pembelajaran. Hal ini menyebabkan suasana kelas sedikit gaduh karena sebagian siswa memilih untuk bermain dengan temannya. Maka guru membutuhkan model pembelajaran

Copyright C2020, JRPD, ISSN 2615 - 1723 (Print), ISSN 2615 - 1766 (Online) 
yang tepat untuk menarik perhatian dan antusia siswa.

Permasalahan ini diselesaikan dengan menciptakan suasana kelas yang menyenangkan sebagai upaya menningkatkan hasil belajar siswa melalui implementasi model pembelajaran Example Non Example. Permasalahan dan tujuan penelitian ini sebagai dasar penulis untuk melakukan penelitian tindakan kelas sebagai upaya meningkatkan hasil belajar siswa melalu implementasi model pembelajaran Example Non Example.

Suprijono (2013:7) berpendapat bahwa hasil belajar adalah perubahan perilaku secara keseluruhan bukan hanya salah satu aspek potensi kemanusiaan saja. Sedangkan menurut Jihad (2012:14) hasil belajar merupakan pencapaian bentuk perubahan perilaku yang cenderung menetap dari ranah kognitif, afektif, dan psikomotoris dari proses belajar yang dilakukan dalam waktu tertentu.

Menurut Lindgren yang dikutip oleh Suprijono (2009: 7) hasil belajar meliputi kecakapan, informasi, pengertian dan sikap. Hasil belajar adalah perubahan perilaku secara keseluruhan bukan hanya salah satu aspek potensi kemanusiaan saja, sedangkan merujuk kepada pemikiran Suprijono (2009: 5), hasil belajar berupa:

1. Informasi verbal yaitu kapabilitas mengungkapkan pengetahuan dalam bentuk bahasa, baik lisan maupun tertulis. Kemampuan merespon secara spesifik terhadap rangsangan spesifik. Kemampuan tersebut tidak memerlukan manipulasi simbol, pemecahan masalah maupun penerapanaturan.

2. Kemampuan intelektual yaitu kemampuan mempresentasikan konsep dan lambang. Keterampilan intelektual terdiri dari kemampuan mengategorisasi, kemampuan analitis-sintesis faktakonsep dan mengembangkan prinsippprinsip keilmuan.

3. Strategi kognitif kecakapan menyalurkan dan mengarhkan aktivitas kognitifnya sendiri.
4. Keterampilan motorik yaitu kemampuan melakukan serangkaian gerak jasmani dalam urusan koordinasi, sehingga terwujud otomatisme gerak jasmani.

5. Sikap adalah kemampuan menerima atau menolak objek berdasarkan penilaian terhadap objek tersebut.

Berdasarkan dari pengertian-pengertian di atas dapat ditarik kesimpulan bahwa pengertian hasil belajar adalah perubahan perilaku dan pengetahuan secara keseluruhan yang diperoleh seseorang setelah menerima pengalaman belajar.

Menurut Sudjana (2016: 4) menyatakan tujuan penilaian hasil belajar adalah sebagai berikut:

1. Mendeskripsikan kacakapan belajar para siswa sehingga dapat diketahui kelebihan dan kekurangannya dalam berbagai bidang studi atau mata pelajaran yang ditempuhnya.

2. Mengetahui keberhasilan proses pendidikan dan pengajara di sekolah, yakni seberapa jauh keefektifannya dalam mengubah tingkah laku para siswa kea rah tujuan pendidikan yang diharapkan.

3. Menentukan tindak lanjut penilaian, yakni melakukan perbaikan dan kesempurnaan dalam hal program pendidikan dan pengajaran serta strategi pelaksanaannya. Memberikan pertanggungjawaban (accountability) dari pihak sekolah kepada pihak-pihak yang berkepentingan.

Model pembelajaran menurut Avisca (2018: 131) yaitu kerangka konseptual berisi sintak pembelajaran yang melukiskan prosedur sistematis untuk mencapai tujuan pembelajaran. Sedangkan Mawardi (2017: 26) berpendapat model pembelajaran berupa kerangka konseptual yang sistematis dalam mengimplikasikan sintak pembelajaran.Huda (2014: 215) berpendapat bahwa model pembelajaran Example Non Examplemerupakan suatu model pembelajaran yang menggunakan mpendekatan pembelajaran berbasis komunikasi dalam kegiatan pembelajaran. 
Sedangkan model pembelajaran Example Non Examplemenurut Kurniasih (2015: 32) adalah langkah untuk mensiasati siswa agar dapat mengidentifikasi sebuah konsep.

Berdasarkan dari pendapat di atas maka dapat dimpulkan bahwa model pembelajaran Example Non Exampleadalah model pembelajaran yang berupa kerangka kontekstual dalam sebuah sintaks berbasis komunikasi untuk mensiasati siswa untuk mengidentifikasi sebuah konsep.

\section{METODE}

Penelitian ini menggunakan jenis Penelitian Tindakan Kelas (PTK) yang dilaksanakan di SD Negeri Panjang 03 Ambarawa pada siswa kelas 3 tema 1 Diriku dengan subtema 2 Tubuhku semester I Tahun Ajaran 2019/2020. Siklus 1 dilaksanakan pada minggu pertama bulan Agustus 2019 dan siklus 2 dilaksanakan pada minggu kedua bulan Agustus 2019. Subjek penelitiannya yaitu siswa kelas 1A SD Negeri Panjang 03 Ambarawa dengan jumlah 24 siswa yang terdiri dari siswa 14 laki-laki dan 10 siswa perempuan. Tahapan penelitian dibagi menjadi perencanaan, pelaksanaan tindakan, observasi, dan refleksi.

Peneliti menggunakan teknik pengumpulan data berupa: 1) Pedoman wawancara adalah teknik untuk mengetahui masalah yang dialami guru dan siswa dalam proses pembelajaran, 2) Lembar observasi sebagai teknik untu mengukur kemampuan menganalisis siswa, 3) Tes merupakan teknik untuk mengukur hasil belajar siswa, dan 4) Teknik dokumentasi untuk melakukan tindak lanjut yang akan diberikan kepada siswa. Peneliti menggunakan teknik analisis data dari hasil wawancara, hasil observasi, tes, dan pegamatan hasil dokumentasi untuk mendapatkan hasil penelitian yang dibutuhkan.

Sedangkan untuk mengetahui tingkat keberhasilan penelitian peneliti menggunakan teknik analisis data berupa deskriptif kualitatif meliputi data masalah yang dihadapi guru dan siswa dalam proses pembelajaran. Sedangkan teknik analisis menggunakan deskriptif kuantitatif menghasilkan data yang meliputi analisis hasil belajar siswa. Kriteria keberhasilan PTK ini ditetapkan jika hasil belajar seluruh siswa mencapai KKM sebesar 70.

\section{HASIL DAN PEMBAHASAN}

\section{Hasil Penelitian \\ Pra Siklus}

Hasil penelitian pada pra siklus diperoleh data sebagai berikut:

Tabel 1 Hasil Belajar Pra Siklus

\begin{tabular}{crcc}
\hline No. & Kategori & Frekuensi & Persentase (\%) \\
\hline 1. & Tuntas & 11 & 46 \\
2. & Tidak Tuntas & 13 & 54 \\
\hline & Jumlah & 16 & 100 \\
\hline
\end{tabular}

Sumber: Data Sekunder

Pada tabel 1, menunjukkan bahwa hasil belajar pada pra siklus ada 11 siswa atau $46 \%$ yang tuntas. Sedangkan 13 siswa atau 54\% masih dalam kategori tidak tuntas. Kriteria ketuntasan minimal (KKM) telah ditetapkan yakni $\geq 70$, maka harus segera dilakukan perbaikan pembelajaran melalui Penelitian Tindakan Kelas (PTK).

Hasil belajar pra siklus siswa kelas 1A SD Negeri Panjang 03 Ambarawa semester I tahun pelajaran 2019/2020 dapat disajikan dalam bentuk grafik pada gambar 1 berikut. 


\section{Persentase Ketuntasan Hasil Belajar}

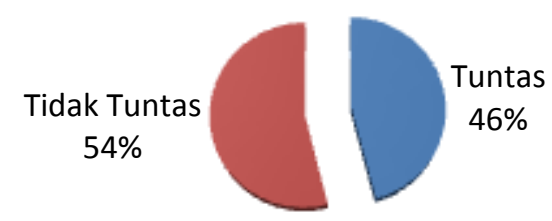

Gambar 1 Diagram Lingkaran Hasil Belajar Pra Siklus

Berdasarkan gambar 1 nampak hasil belajar pra siklus siswa kelas 1A SD Negeri Panjang 03 Ambarawa semester I tahun pelajaran 2019/2020 masih rendah yang ditunjukkan pada persentase ketuntasan terdapat (54\%) siswa masih dalam kriteria tidak tuntas lebih besar dari kriteria tuntas (46\%).

Prestasi belajar siswa kelas 1A SD Negeri Panjang 03 Ambarawa dapat dilihat dari nilai minimum, nilai maksimum, dan nilai rata-rata kelas. Deskripsi nilai secara rinci disajikan melalui tabel 2 berikut.

Tabel 2 Deskripsi Prestasi Belajar Pra Siklus

\begin{tabular}{|l|c|}
\hline \multicolumn{1}{|c|}{ Deskripsi } & Nilai \\
\hline Nilai Minimum & 50 \\
\hline Nilai Maksimum & 85 \\
\hline Nilai Rata-rata & 69,7 \\
\hline \multicolumn{2}{|c|}{ Sumber: Data Sekunder } \\
\hline
\end{tabular}

Berdasarkan tabel 2 nampak bahwa nilai rata-rata yang diperoleh siswa kelas $1 \mathrm{~A} \mathrm{SD}$ Negeri Panjang 03 Ambarawa semester I tahun pelajaran 2019/2020 pra siklus berada di bawah $\mathrm{KKM} \geq 70$. Pengukuran hasil belajar diperoleh dari pengukuran tes saja. Kondisi hasil belajar siswa kelas kelas 1A SD Negeri Panjang 03 Ambarawa semester I tahun pelajaran 2019/2020 pra siklus ini menimbulkan permasalahan belajar, sehingga perlu diadakan perbaikan pembelajaran menggunakan model pembelajaran Example Non Example.

\section{Siklus I}

Hasil belajar pada siklus 1 diperoleh dari tes formatif, pengukuran sikap dan keterampilan siswa dalam melaksanakan kegiatan pembelajaran menggunakan model pembelajaran Example Non Example. Hasil belajar pada siklus 1 , secara rinci disajikan melalui tabel 3 berikut.

Tabel 3 Hasil Belajar Siswa Menggunakan Model Pembelajaran Example Non Example Siklus 1

\begin{tabular}{clcc}
\hline No & Kategori & Frekuensi Siswa & Persentase (\%) \\
\hline 1 & Tuntas & 19 & 79 \\
2 & Tidak Tuntas & 5 & 21 \\
\hline & Jumlah & 16 & 100
\end{tabular}

Berdasarkan tabel 3, nampak bahwa peningkatan dari sebelumnya (pra siklus) 11 hasil belajar siswaberdasarkan mengalami siswa atau 46\% mencapai ketuntasan dan 13 
siswa atau $54 \%$ belum mencapai ketuntasan. Hasil belajar siklus 1 ini, menunjukkan adanya kenaikan persentase sebelumnya yakni 33\%.
Hasil belajar siswa siklus 1 dapat disajikan melalui gambar 2 di halaman berikut

\section{Persentase Ketuntasan}

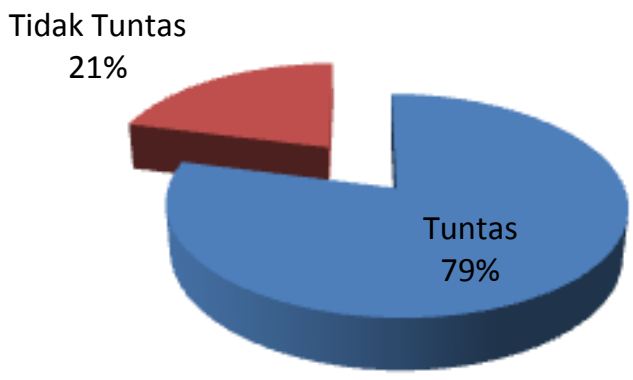

Gambar 2 Diagram Lingkaran Hasil Belajar Siswa Menggunakan Model Pembelajaran Example Non Example Siklus 1

Berdasarkan gambar 2 diagram lingkaran hasil belajar siswa kelas $1 \mathrm{~A}$ SD Negeri Panjang 03 Ambarawa semester I tahun pelajaran 2019/2020 siklus I, tingkat persentase ketuntasan pada kriteria tidak tuntas (21\%) dan 79\% mencapai kriteria tuntas.

Adapun deskripsi hasil belajar siklus 1, secara rinci disajikan melalui tabel 4di halaman berikut.

Tabel 4 Deskripsi Nilai Minimum, Nilai Maksimum dan Nilai Rata-Rata Hasil Belajar Siswa Siklus 1

\begin{tabular}{|l|c|}
\hline \multicolumn{1}{|c|}{ Deskripsi } & Nilai \\
\hline Nilai Minimum & 65 \\
\hline Nilai Maksimum & 100 \\
\hline Nilai Rata-rata & 73,5 \\
\hline
\end{tabular}

Berdasarkan tabel 4, nampak bahwa nilai minimum hasil belajar yang dicapai siswa kelas 1A SD Negeri Panjang 03 Ambarawa semester I tahun pelajaran 2019/2020 siklus 1, menggunakan model pembelajaran Example Non Examplemeningkat menjadi 65, yang sebelumnya (pra siklus) hanya mencapai 50. Perolehan nilai maksimum meningkat menjadi 100 , yang sebelumnya (pra siklus) hanya mencapai 85 , dan nilai rata-rata kelas yang diperoleh meningkat menjadi 73,5, yang sebelumnya (pra siklus) hanya mencapai 69,7. Perolehan nilai ini, menunjukkan peningkatan yang signifikan dibandingkan dengan pembelajaran sebelumnya, yang masih berbasis guru dan tidak menggunakan desain pembelajaran tertentu. Artinya peningkatan hasil belajar siswa pada pembelajaran siklus 1 adalah signifikan atau bermakna dengan persentase peningkatan sebesar $33 \%$.

\section{Siklus II}

Hasil belajar pada siklus 2 diperoleh dari tes formatif, pengukuran sikap dan keterampilan siswa dalam melaksanakan kegiatan pembelajaran menggunakan model pembelajaran Example Non Example.

Hasil belajar pada siklus 2 secara rinci disajikan melalui tabel 5 di halaman berikut.

Tabel 5 Hasil Belajar Siswa Menggunakan Model pembelajaran Example Non Example Siklus 2

\begin{tabular}{|c|l|c|c|}
\hline No & $\begin{array}{c}\text { Kriteria } \\
\text { Ketuntasan }\end{array}$ & Frekuensi & $\begin{array}{c}\text { Persentase } \\
(\mathbf{\%})\end{array}$ \\
\hline 1 & Tuntas & 24 & 100 \\
\hline 2 & $\begin{array}{l}\text { Tidak } \\
\text { Tuntas }\end{array}$ & 0 & 0 \\
\hline \multicolumn{2}{|l|}{ Jumlah } & 16 & 100 \\
\hline
\end{tabular}


Berdasarkan tabel 5, nampak bahwa hasil belajar siswa mengalami peningkatan dari sebelumnya yakni 19 siswa menjadi 24 siswa yang mencapai kriteria tuntas. Dari kriteria yang diperoleh menunjukkan bahwa $100 \%$ siswa tuntas dalam belajar dengan nilai $\geq 70$. Peningkatan hasil belajar ini bermakna, karena dalam pembelajaran ada tindakan belajar yang menggunakan model pembelajaran Example Non Examplemengakibatkan siswa terlibat langsung dalam belajar.

Hasil belajar yang diperoleh siswa dapat disajikan dalam bentuk diagram lingkaran, melalui gambar 3 berikut:

\section{Persentase Ketuntasan}

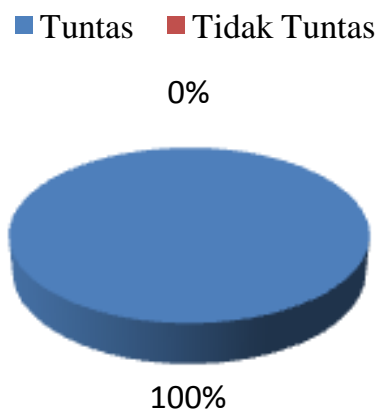

Gambar 3 Diagram Lingkaran Hasil Belajar Siswa Menggunakan Model Pembelajaran Example Non Example Siklus 2

Berdasarkan gambar 3 nampak bahwa persentase ketuntasan pada kriteria tuntas hasil belajar siswa kelas 1A SD Negeri Panjang sebesar 100\%.

03 Ambarawa semester I tahun pelajaran Adapun deskripsi hasil belajar siklus 1, 2019/2020 siklus 2 sangat tinggi dengan secara rinci disajikan melalui tabel 6 di halaman berikut.

Tabel 6 Deskripsi Nilai Minimum, Nilai Maksimum dan Nilai Rata-

Rata Hasil Belajar Siswa Menggunakan Model Pembelajaran

Example Non ExampleSiklus 2

\begin{tabular}{|c|c|}
\hline Deskripsi & Nilai \\
\hline Nilai Minimum & 75 \\
\hline Nilai Maksimum & 90 \\
\hline Nilai Rata-rata & 87,6 \\
\hline
\end{tabular}

Sumber: Data Sekunder

Berdasarkan tabel 6 nampak bahwa nilai minimum hasil belajar yang dicapai siswa kelas 1A SD Negeri Panjang 03 Ambarawa menggunakan model pembelajaran Example Non Examplesebesar 75 , nilai maksimum sebesar 90 , dan nilai rata-rata kelas yang diperoleh sebesar 87,6. Perolehan ini menunjukkan peningkatan yang signifikan dibandingkan dengan pembelajaran sebelumnya pada siklus 1 . Artinya peningkatan hasil belajar siswa nampak pada kenaikan nilai minimum dari
50 menjadi 75; kenaikan nilai maksimum dari 85 meningkat menjadi 90, dan nilai ratarata dari 669,7 menjadi 87,6 . Hasil belajar yang diperoleh dalam siklus 2 , baik nilai minimum, nilai maksimum maupun nilai rata-rata, menunjukkan nilai di atas 70 , yang merupakan batas minimal ketuntasan. Dengan demikian, pencapaian hasil belajar pada siklus 2, telah mencapai persentase peningkatan ketuntasan belajar $100 \%$ atau hampir seluruh siswa (24 siswa) kelas 1A SD 
Negeri Panjang 03 Ambarawa semester I tahun pelajaran 2019/2020.

Hasil belajar pada pembelajaran tema 1 Diriku dengan subtema 2 Tubuhku diukur melalui tes hasil belajar pada pra siklus nilai rata-rata 69,7 dan ketuntasan 46\%. Hasil belajar pada pra siklus menunjukkan belum mencapai ketuntasan. Untuk mencapai ketuntasan dilakukan penerapan pembelajaran menggunakan model pembelajaran Example Non Exampledan terjadi peningkatan. Siklus I mencapai nilai rata-rata 73,5 dan ketuntasan $79 \%$. Pada siklus II hasil belajar siswa mencapai nilai rata-rata 87,6 dan ketuntasan $100 \%$.

Penerapan model pembelajaran Example Non Exampleberdampak pada suasana kelas dan minat belajar siswa. Perubahan minat belajar siswa antara lain lebih aktif, berani mengemukakan pendapat sedangkan suasana kelas menjadi efektif dan menyenangkan. Pada siklus II pembelajaran menjadi lebih baik karena penerapan model pembelajaran Example Non Exampledapat meningkatkan aktivitas siswa dengan mencari pasangan sambil belajar mengenai suatu konsep atau topik dalam suasana yang menyenangkan dan dapat mengendalikan suasana kelas agar lebih kondusif dan efektif demi kelangsungan proses pembelajaran.

Dari uraian diatas dapat diperoleh hasil penelitian bahwa penerapan model pembelajaran Example Non Exampledapat meningkatkan hasil belajar siswa. Hasil belajar siswa pada pra siklus rata-rata 69,7 menjadi 87,6 pada siklus II. Peningkatan juga terjadi pada hasil ketuntasan belajar siswa dari $46 \%$ atau 11 siswa pada pra siklus menjadi $100 \%$ atau 24 siswa pada siklus II.

Hasil pengamatan yang dilakukan selama proses pembelajaran diperoleh data perbandingan dari pra siklus, siklus I, dan siklus II sebagai berikut :

Tabel 7 Perbandingan Hasil Belajar Siswa Pra Siklus, Siklus I, dan Siklus II

\begin{tabular}{ccccc}
\hline No & Hasil Belajar & Pra Siklus & Siklus I & Siklus II \\
\hline 1. & Nilai Tertinggi & 85 & 100 & 90 \\
2. & Nilai Terendah & 50 & 65 & 75 \\
3. & Nilai Rata-rata & 69,7 & 73,5 & 87,6 \\
4. & Ketuntasan Belajar & $46 \%$ & $79 \%$ & $100 \%$ \\
\hline
\end{tabular}

Hasil penelitian menghasilkan data pada tabel 1 yang menunjukkan ada kenaikan hasil belajar siswa. Nilai rata-rata pada pra siklus 69,7 , pada siklus I nilai rata-rata 73,5 , dan pada siklus II nilai rata-rata 87,6. Data tersebut membuktikan bahwa pembelajaran dengan model pembelajaran Example Non Exampledapat meningkatkan hasil belajar siswa.

Tabel 8 Perbandingan Ketuntasan Hasil Belajar Siswa Pra Siklus, Siklus I, dan Siklus II

\begin{tabular}{ccccc}
\hline No & Pembelajaran & Tidak Tuntas & Tuntas \\
\hline 1. & Pra Siklus & 13 siswa $(54 \%)$ & 11 siswa $(46 \%)$ \\
2. & Siklus I & 5 siswa $(21 \%)$ & 19 siswa $(79 \%)$ \\
3. & Siklus II & 0 siswa $(0 \%)$ & 24 siswa $(100 \%)$ \\
\hline
\end{tabular}


Dari dua tahap penelitian yang dilakukan diperoleh data hasil penelitian dalam tabel perbandingan dari pra siklus, siklus I, dan siklus II sebagai berikut:

Tabel 9 Perbandingan Hasil Belajar Siswa Pra Siklus, Siklus I, dan Siklus

\begin{tabular}{ccccc}
\hline No & Hasil Belajar & Pra Siklus & Siklus I & Siklus II \\
\hline 1 & Nilai Tertinggi & 85 & 100 & 90 \\
2 & Nilai Terendah & 50 & 65 & 75 \\
3 & Nilai Rata-rata & 69,7 & 73,5 & 87,6 \\
4 & Kenaikan & - & $20 \%$ & $17,2 \%$ \\
\hline 5 & Tuntas & 11 siswa (46\%) & 19 siswa (79\%) & 24 siswa (100\%) \\
\hline
\end{tabular}

Data diatas menunjukkan bahwa ada kenaikan hasil belajar yang signifikan dari pra siklus, siklus I, dan siklus II. Hasil siklus I menunjukkan ada kenaikan dari $46 \%$ yang mencapai KKM pada pra siklus menjadi $79 \%$ pada siklus I. Siklus II pun terbukti ada kenaikan dalam ketuntasan KKM dari 79\% pada siklus I menjadi $100 \%$ pada siklus II. Data tersebut membuktikan bahwa pembelajaran dengan model pembelajaran Example Non Exampledapat meningkatkan hasil belajar siswa dari $46 \%$ pada pra siklus menjadi $100 \%$ pada siklus II.

\section{SIMPULAN}

Berdasarkan hasil penelitian dapat disimpulkan bahwa implementasi model pembelajaran Example Non Exampledapat meningkatkan hasil belajar dapat: 1) meningkatkat aktivitas belajar siswa, 2) meningkatakan hasil belajar pada pembelajaran tema 1 Diriku dengan subtema 2 Tubuhku siswa siswa kelas 1 SD Negeri Panjang 03 Ambarawa pada semester II tahun ajaran 2019/2020. Berpijak pada hasil penelitian ini, disarankan kepada para guru menggunakan model pembelajaran Example Non Exampledalam pembelajaran untuk melatih siswa berperan aktif dalam proses pembelajaran, melatih siswa bersosial, dan menciptakan suasana kelas yang kondusif, efektif, menyenangkan.

Berpijak pada hasil penelitian ini, disarankan kepada para guru mengimplementasikan model pembelajaran Example Non Exampledalam pembelajaran untuk melatih siswa berperan aktif dalam proses pembelajaran, melatih siswa bersosial, dan menciptakan suasana kelas yang menyenangkan. Kondisi seperti ini akan meningkatkan hasil belajar siswa dalam proses pembelajaran. Guru harus lebih kreatif supaya materi pembelajaran dapat diterima siswa dengan mudah. Pihak sekolah juga harus berperan serta dalam menyediakan fasilitas yang memadai untuk berlangsungnya proses pembelajaran dengan mengimplementasikan model pembelajaran Example Non Example.

\section{DAFTAR PUSTAKA}

Astriani, R. (2017). Pengaruh Model Pembelajaran Example Non ExampleBerbantu Media Gaser Terhadap Ketrampilan Menulis Deskripsi Siswa Kelas IV SD N Ngesrep 01. Jurnal Pendas Mahakam: 2 (1). 91-99.

Avisca, K.C.W. (2017). Penggunaan Model Pembelajaran Kooperatif Tipe Make A Match Berbantuan Media Speacking Card Sebagai Upaya Peningkatan Hasil Belajar. Satya Widya: 33 (1). 56-63.

Habibah, S. (2016). Penggunaan Model Pembelajaran Examples Non Examples Terhadap Ketuntasan Hasil Belajar Siswa Pada Materi Tokoh-tokoh Pergerakan Nasional Kelas V SDN 70 
Banda Aceh. Jurnal Pesona Dasar: 3 (4) 54-64.

Huda, M. (2014). Model-model Pengajaran dan Pengembangan: Isu-isu Metodis dan Paradigmatis. Yogyakarta: Pustaka Pelajar.

Kurniasih, I., \& Sani, B. (2015). Ragam Modern Penelitian Kuantitatif. Bandung: Alfabet.

Lestari, I. (2017). Perbedaan Hasil Belajar Example Non ExampleTerhadap Siswa Kelas 5 Pada Mata Pelajaran IPA. Jurnal Refleksi Edukatika: 7 (2). 123-126.

Lisnani. (2019). Pengaruh Model Pembelajaran Example Non ExampleUntuk Meningkatkan Hasil Belajar Tematik Bagi Siswa Kelas VI SD. Jurnal Basicedu: 3 (1). 76-82.
Mawardi. (2017). Merancang Model Dan Media Pembelajaran. Scholaria, 8 (1), 26-40.

Noviasari, L. (2019). Meta-Analisis Pengaruh Model Pembelajaran Kooperatif Tipe Example Non ExampleTerhadap Hasil Belajar IPA. Janacitta: 2 (1). 33-38.

Pranoto, H. (2016) Peningkatan Hasil Belajar Siswa Melalui Model Pembelajaran Examples Non Examples Pada Mata Pelajaran IPA Siswa Kelas VI B Semester 1 SD Negeri Turitempel Tahun Pelajaran 2016/2017. Malih Peddas: 7 (1). 46-51.Suryani, Eni dkk. 2018. Pengaruh Model Example Non Example Terhadap Hasil Belajar Pada Materi Sumber Daya Alam di SD. Pedadidaktika: 5 (1). 100-108. 